\title{
ALTERNATIVE TO JOBLESS GROWTH? ALL-INDIA CONTEXT AND A CASE OF PARTICIPATORY DEVELOPMENT SCHEME FROM RURAL TAMIL NADU
}

\begin{abstract}
NOVOTNÝ, J., RAMACHANDRAN, N. (2010): Alternative to jobless growth? All-India context and a case of participatory development scheme from rural Tamil Nadu. Geografie, 115, No. 3, pp. 330-346. - The article outlines some of the problems, challenges, and prospects in relation to contemporary Indian development with a special focus on rural India. The paper seeks to contrast traditional modernization views on development assuming progressive structural transformation through industrialization with Indian reality by stressing the importance of the enhancement of employment, and more generally livelihood, opportunities for the masses of underutilized labor. In addition to a brief discussion of the context at the all-India level, the case of a rural region in central eastern Tamil Nadu is examined to provide a picture of the everyday living conditions of local villagers and to indicate some of the problems and uncertainties they are typically confronted with. The rural development project called Periyar PURA (Providing Urban Amenities to Rural Areas) is then discussed which attempts to present a model of how to tackle some of these problems.
\end{abstract}

KEY WORDS: economic development - India - participatory development - poverty - Periyar PURA.

The article draws on information collected during the stay of Josef Novotný at the Research Information System for Developing Countries in New Delhi and on materials from the Periyar PURA project gathered by the staff and students of Periyar Maniammai University, Thanjavur, Tamil Nadu. The authors would like to thank Kumaran Shanmugam, Tamilmani Eevera, and Sivanantham Mahalingam for their help and useful comments. Josef Novotný also acknowledges support from the research grant MSM 0021620831.

\section{Introduction}

The recent 2009 edition of the World Development Report 2009 has been entitled: "Reshaping Economic Geography". This appealing title was chosen mainly because the report is built on praise for the role of the principle of spatial agglomeration for development. According to this flagship annual World Bank publication, the main key to poverty alleviation and development resides in bigger cities, more migrating people, and the increasing specialization of countries and regions. Referring to the selectively chosen historical evidence, the report suggests that, instead of tackling inherent (spatial) unbalances in economic development by targeted territorial development programmes trying to bring jobs to lagging rural areas, an "efficient and inclusive urbanization" should be promoted. The prescription for achieving this is to put appropriate institutions in place and foster infrastructural and economic integration. In a 
nutshell, the functioning land markets at the local level, migration (functioning labor markets) at the national level, and specialization (achieved through international trade and especially through trade in intermediate goods) at the international level will, as the World Bank's economists believe, eventually bring a better quality of life for all.

However, such blind confidence in the power of the market forces (marketdriven spatial transformations) to work for development without appropriate interventions seems to be lacking in imagination. This linear perspective on developmental transformation proves to be outdated when contrasted to modern theories of development and oversimplified with regard to the complexities of contemporary developing countries. The employment intensity in labor-demanding segments of the economy is increasingly seen as a crucial factor in linking economic growth to poverty reduction. At the same time, there is an increasing emphasis on the utilization of endogenous potentials for employment creation as well as on the associated concepts of endogenous participative development that are inherently local or regional in scale. The concepts of endogenous and participatory development strive to unlock local potential by empowering local citizens, strengthening the quality of physical, human, and social capital in a given region, and enabling people's participation in the management of local assets. In such a way, employment opportunities in local small and medium-sized industries as well as in enterprises operating in nearby towns should be catalyzed. This is viewed as a preferable alternative to the assumptions expressed in the World Development Report 2009 or in some classical development models focusing on economic dualism (e.g. Lewis 1954) explicitly or implicitly expecting rural and small-town dwellers/inhabitants to migrate to large cities in the hope of finding a job in the modern industrial sector. In the concepts of endogenous development, modernity is viewed as generated from within as being not only a matter of the "imported modernization", but also the "modernization of tradition" (Pieterse 2010, p. 96). Although mentioned (idealized) prescriptions of the endogenous development have not been articulated in a single coherent theory, there is a stark contrast between these "alternative" views on development and the growth-centered orthodoxy.

The importance of such alternative conceptions is also supported by the evidence from India that will be presented in this article. It will outline some of the problems, challenges, and prospects in relation to contemporary Indian development with a special focus on rural areas. Our general goal is to contrast traditional modernization assumptions expecting progressive sectoral transformation of the economy with Indian reality by stressing the importance of the enhancement of employment, and more generally livelihood, opportunities for the masses of underutilized and largely informal labor. At the same time, an effort will be made to indicate that action is needed to attain more socially inclusive economic growth. In addition to an illustration of this need at the national level in the first part of the article, the main second part examines the case of rural region in central eastern Tamil Nadu. The first goal here is to exemplify some of the problems local people struggle with in their everyday lives. Second, we wish to discuss the rural development project called Periyar PURA (Providing Urban Amenities to Rural Areas) coordinated by a local university which attempts to present a model of how to tackle some of the problems at local and regional level. 
Last but not least, the pragmatic goal of this paper is to bring together material that could be later utilized for a more intensive field research in considered rural area. As such, we draw mainly on secondary data from different sources including national level data from several Indian government agencies, disaggregated local level data from the Tamil Nadu Below Poverty Line Survey, and various information on the region and project in question from the Periyar PURA records.

The remainder of the paper is organized as follows: Section 2 illustrates the problem of the "jobless growth" in India by presenting some macro-level development trends. The central part of the paper consists of Section 3 which presents the regional level evidence from rural Tamil Nadu. In Section 3.1. we briefly describe the region in question and examine living conditions of local villagers. The Periyar PURA project is then discussed in Section 3.2. Section 4 concludes by summarizing main findings.

\section{Beyond economic growth: all-India socioeconomic context}

It is in rural India where one of the keys to the global development puzzle lies. India is not only home to approximately one-sixth of the world's population but also to a staggering one-third of the world's extremely poor; the majority of whom still live in rural areas (World Development Indicators 2009). Concurrently with the celebration of the robust growth of the Indian economy and its progressive (though selective) integration into the system of international division of labor, strong calls for actions that would make the growth more socially inclusive have emerged. ${ }^{1}$ These have been based on the belief that liberalization and reliance on strictly economic incentives are not sufficient for achieving what has become known as participatory economic growth.

Similarly, it is now widely acknowledged that a favourable macroeconomic performance has been a necessary but not sufficient condition for the significant reduction of poverty among the Indian population. According to official figures, $28 \%$ of the Indian population had an income below the national poverty line in $2004-5$ in comparison with $55 \%$ in the 1970 s. However, the rate of poverty decline has not been higher in the post-reform period (i.e. since the adoption of the "New Economic Policy" in 1991). It should also be noted that the official national poverty line is extremely low - approximately 12 Rupees (0.27 USD) a day per capita (with some variation among different Indian states and rural and urban areas), which is equivalent to the price of a bottle of mineral water bought from a Delhi vendor for example. The majority of people are actually supposed to live on an income not far above this poverty line. According to analysis by Sengupta et al. (2008), a striking $77 \%$ of the population has been estimated to earn less than 20 Rupees per day. Moreover, the improvements in some other non-economic dimensions of social development have been even less favourable. The most pronounced example is an exceptionally high and persistent level of child malnutrition (an astounding 46\% in 2005-6) on which the economic boom has almost no effect (e.g. Chatterjee 2007).

1 This is also highlighted in the National Eleventh Five Year Plan 2007-12 (Eleventh Five Year Plan 2007-12). 
Tab. 1 - The structure of Indian GDP and employment (2006-2007)

\begin{tabular}{|lccc|}
\hline Indicator & Agriculture and allied (\%) & Industry (\%) & Services (\%) \\
\hline GDP & 19 & 26 & 55 \\
Employment & 60 & 17 & 23 \\
\hline
\end{tabular}

Source: Reserve Bank of India, Handbook of Statistics on Indian Economy 2008 Note: Industry includes construction

The economic growth has been driven by the expansion of services that have been growing consistently faster than other sectors (Eleventh Five Year Plan 2007-12). It is argued that the pattern of Indian development has been a specific one and that the country may be able to skip the intermediate industrialization-led phase in the transformation of its economic structure. The interpretation of this "idiosyncratic pattern of development" (Kochhar et al. 2006, p. 981) is however ambiguous. While for some of the authors the boom of services and the relative lag of manufacturing evokes an optimistic view towards Indian development perspectives (e.g. Lal 2008), serious concerns have been raised about the "jobless" nature of the economic growth (e.g. Dasgupta, Singh 2005). The latter warn of an insufficient demand for the rapidly growing labor force (a steady $2 \%$ annually) of which only a fraction is employable in the newly emerging service activities. In 2008 the sector of IT-BPO (Information Technologies and Business Process Outsourcing) services directly employed less than $0.5 \%$ of the Indian labor force and indirect job creation is estimated at $1.8 \%$. On the other hand, the IT-BPO sector accounted for almost one-fourth of Indian export (Indian IT-BPO Industry 2009). Moreover, even within the manufacturing sector, the growth has been based relatively more on skill-intensive rather than labor-intensive activities, at least when compared to the trajectories of other rapidly developing (Asian) countries (Kochhar et al. 2006).

The employment figures in Table 1 reinforce these concerns. Although it is agriculture where the majority of Indians earn their livelihoods, recent growth in agriculture has been slower than in other sectors, largely concentrated outside the segment comprising small farmers, and more volatile depending on monsoons, droughts and other environmental but also political-economic factors. These structural imbalances are vital to increasing inequality (in its various dimensions) which, in turn, worsens the growth elasticity of poverty reduction when even high aggregate growth rates do not themselves lead to an adequate decline of poverty.

The relevance of the aforementioned arguments is bolstered by the fact that recent years of increasing macroeconomic growth have been accompanied by the declining rate of employment growth (Sharma 2006, p. 2079). It also has to be remembered that the overwhelming majority of workers are employed in a massive unorganized sector (see Table 2 ). ${ }^{2}$ From the overall stock of an

2 National Commission for Enterprises in the Unorganised Sector (NCEUS) defines the unorganized sector as comprising all unincorporated private enterprises (both agricultural and non-agricultural) employing less than 10 persons. The informal workers then consist of those employed in the unorganized and organized sectors without any employment and social security benefits provided by the employers (The Challenge of Employment in India 2009, p. 3). 
Tab. 2 - Estimated structure of Indian workforce (in millions)

\begin{tabular}{|l|c|c|c|c|c|c|}
\hline \multirow{2}{*}{ Sector } & \multicolumn{2}{|c|}{ Informal workers } & \multicolumn{2}{c|}{ Formal workers } & \multicolumn{2}{c|}{ Total } \\
\cline { 2 - 7 } & $1999-2000$ & $2004-2005$ & $1999-2000$ & $2004-2005$ & $1999-2000$ & $2004-2005$ \\
\hline Unorganized & 341 & 394 & 1 & 1 & 342 & 395 \\
Organized & 20 & 29 & 34 & 33 & 54 & 63 \\
Total & 362 & 423 & 35 & 35 & 397 & 458 \\
\hline
\end{tabular}

Source: estimated by NCEUS drawing on Indian National Sample Survey, 55th and 61st round

estimated 458 million workers, 394 million (86\%) operate in the unorganized sector (of which $63 \%$ are self-employed) mostly as informal workers with almost no access to social protection and usually with high vulnerability with respect to practices such as work irregularity, payment of less than minimal remuneration, risky work conditions, abuses of child labour etc. In fact, there is a strong relationship between the quality of employment and social and poverty characteristics (Sengupta et al. 2008).

The unorganized (and informal) sector is usually seen as a transitory phenomenon that is expected to decline in the course of economic modernization at the expense of the expansion of organized/formal employment. However, the comparison of figures in Table 2 suggests that in the Indian case rather the contrary is true. There was an increase in the absolute number of informal workers between 2000 and 2005, and this trend has probably remained the same in the period since 2005 (The Challenge of Employment in India 2009). Interestingly, the figures also show that the relative growth of informal employment was more rapid within the organized rather than the unorganized sector. This informalization is also related to the flexibilization of employment in the organized sector that is suggested by the increasing use of contract labor by employers in order to benefit from more flexible labor practices. For example, Sharma (2006, p. 2081) notes that the proportion of contract workers to total workers increased from $12 \%$ to $23 \%$ between 1990 and 2002 . Notably, the author also refers to the fact that the growth of non-permanent employment does not depend on the size of the organizational units; the relative share of contractual employees increased significantly even in the big firms with 500 and more employees.

Not denying the importance of good macroeconomic records, the comments above signify an essential need for supplementary measures that would turn frequently used notions of pro-poor or inclusive growth into reality. This need is additionally supported by the local level evidence from different parts of India as well as from other developing countries. An interesting paper by Krishna (2007) overviews retrospective field data from 223 villages in India, Kenya, Peru, and Uganda in order to uncover more nuanced dynamics beyond the aggregate poverty numbers. This research revealed that during a particular period of time a large number of households escaped from poverty but simultaneously a large number of other households fell into poverty, often without a significant impact on the aggregate poverty rate. Importantly, different sets of reasons are reported for the escape from and decline into poverty, respectively. On the one hand, poor health and health-related expenses were the most often 
reported by households as accounting for their descent into poverty (between $60 \%$ and $88 \%$ of all cases in particular countries). On the other hand, the single most prevalent reason for escaping from poverty was income diversification through establishing additional sources of livelihood in terms of both on-farm and off-farm activities (from 35\% to $78 \%$ of the reported cases).

There are now a variety of ways in which the challenges identified above can be addressed. While in the second part of this article an example of a locally-based initiative will be described, let us conclude this section with a brief note concerning the role of large-scale government programmes. Although these actions themselves usually do not provide systematic solutions, they may play an extremely important role if designed to alleviate the problems of the segments of population in greatest need. With regard to the anti-poverty programmes directed to attempts at strengthening job and livelihood opportunities, there are three general types of such government schemes in India. These include programmes to promote self employment, schemes to provide new wage employment opportunities, and those focused specifically on backward and disadvantaged social groups (see Saxena 2007). Despite India has a long tradition of such efforts, many of them have failed to fulfil their initial expectations. Typically, it was because of a lack of transparency, bureaucratic implementation and institutionalized practices of corruption, and extensive rent-seeking behaviour (e.g. Corbridge et al. 2005; Moore, Jadhav 2006). A notable recent attempt to provide basic livelihood security for rural citizens should be mentioned in terms of the National Rural Employment Guarantee Act (recently renamed as Mahatma Gandhi Rural Employment Guarantee Act). This gigantic programme was launched in 2006 with promises of bringing about a groundbreaking change by guarantying the universal right to at least 100 days of paid employment per year for any rural household, whose adult members are willing to do basic manual work. After the two-year trial period, the scheme has been extended to almost all of the Indian districts with the harmonized wage of 100 Rupees per working day. Almost 45 million rural households were reached during the financial year 2008-2009 while the expenditure allocated for the scheme in 2009-2010 accounts for 3.9\% of the national budget (Union Budget 2009-2010). The programme has sought to incorporate a number of safeguard mechanisms such as social audits, a ban on contractors or the stress on the involvement of the local community administration (gram panchayats) in order to reduce the deficiencies experienced by previous schemes. Despite the fact that the quality of implementation varies immensely from place to place (see CAG 2007; Dreze, Oldiges 2009), it is the future that will determine whether this programme fulfils its ambitions to be the most powerful rural development initiative ever undertaken or whether a large part of these expectations remain only on paper.

\section{An example of regional development from rural Tamil Nadu}

Bearing in mind the context of the all-India challenges outlined in the previous section, the rest of the article examines a local-level example of a rural region in central eastern Tamil Nadu. Firstly, some basic facts about the region are mentioned and the socioeconomic profile of the population living in 
the considered villages is elaborated. Secondly, we will discuss the development project called Periyar PURA (Periyar was a famous social reformer and PURA means "Providing of Urban Amenities to Rural Areas"), which is trying to strengthen the opportunities of villagers and which is administered by the nearby Periyar Maniammai University (see also http://www.periyarpura.org).

\subsection{Periyar PURA region and profile of median family}

The region covered by the Periyar PURA project (therefore, the label "Periyar PURA region" is used further in the text) encompasses an area comprised of 65 villages in the south west of Thanjavur district and north of Pudukkottai district. ${ }^{3}$ More concretely, these villages are situated in three neighbouring blocks including south west of Thanjavur block and south of Budalur block (both in Thanjavur district) and north of Gandarvakkottai block (in Pudukkottai district). ${ }^{4}$ The overall area of the region is 486 square $\mathrm{km}$ and the total population reaches almost 100,000 . Although the Tamil Nadu as a whole belongs with the more developed Indian states, both Thanjavur and Pudukkottai districts have mostly an average or less than average level of socioeconomic indicators if compared to other Tamil Nadu districts (Government of Tamil Nadu 2003). In addition, considerable spatial disparities can be found inside the districts which primarily reflect differences between urban centres and rural villages. For example, the rate of adult literacy in 2003 was only $62 \%$ for the villages in the Periyar PURA region, while this figure can be compared with $80 \%$ reported for the nearby city of Thanjavur or with $74 \%$ recorded for Tamil Nadu as a whole.

The larger part of this rural area is situated outside of the fertile Kaveri river delta which is known as the "rice bowl" of Tamil Nadu. ${ }^{5}$ As a consequence, only a smaller part of the agricultural land is thus irrigated and the dominant cultivation system is rain-fed agriculture. Water and water management issues are crucial here. In addition to shortages of water for agriculture, the quality of drinking water is also a problem. Agricultural production, which is the primary occupation for two-thirds of the villagers, is nevertheless subject to seasonality and for a large share of agricultural workers it often generates full employment for not more than three months per year. The prevalent soil structure is red loam and the main cultivation crops are paddy and sugarcane in more water-rich parts and oil seeds (groundnut, sesame), pulses (red gram, green gram), sorghum, cashew, or coconut in the rest of the area.

3 The geographic position of the region is indicated in the satellite image that can be accessed on http://natur.cuni.cz/ pepino/Periyar_PURA.html in which the Periyar PURA region roughly corresponds to the circled area with the center in the Sengipatti village (marked with $\mathrm{A}$ in the linked satellite image) and a semi-diameter of approximately $10 \mathrm{~km}$.

4 There are 32 administrative districts in Tamil Nadu and each district comprises several sub-districts (taluks). In rural areas taluks consist of blocks composed from villages or village clusters with gram panchayats as administrative bodies.

5 This interface between "wet" and "dry" parts of the region is obvious from the satellite image that can be accessed on http://natur.cuni.cz/ pepino/Periyar_PURA.html. 
According to the Below Poverty Line (BPL) Census conducted in 2002-3, the villages in the Periyar PURA region have a high share (63\%) of population in the categories known as Scheduled Castes, Tribes and Other Backward Classes. As per the same data, one-third of the population was classified as living below the poverty line when applying a multidimensional poverty definition. Although the BPL Census has been subject to criticism with respect to its main objective, which was to identify the rural households living below the poverty line who could be assisted under various anti-poverty programmes (e.g. Sundaram 2003), it provides interesting and detailed information about the different dimensions of the everyday lives of rural families. These data can now be utilized for the purpose of reconstructing a profile of the typical or median family living in the considered region. This exercise may provide a better understanding of the constraints that local villagers struggle with as well as the challenges they must face. ${ }^{6}$

Let us begin with the economic situation of this median household. The monthly income of such a family falls within the range of 500-1,499 Rupees (between 11 and 37 USD). Usually, the family does not possess any agricultural land and if it does, then it is not more than 1 ha of un-irrigated or less than 0.5 ha of irrigated holdings. The members of the median family have on average less than six pieces of normal wear clothing per person. Their livelihood typically depends on the casual labor of the adult male members. Less often, the family obtains its resources solely from subsistence agriculture. The probability that regular wage employment is the primary source of livelihood is only $17 \%$. The typical house the median family lives in is a kind of "kutcha" house with the walls and roof built from materials such as un-burnt bricks, bamboos, mud, grass, or thatch. The house does not have a toilet; therefore open defecation is the prevailing system of sanitation. The source of drinking water is mostly not within the house, but usually not far from it: it is mostly located within a walking distance of $0.5 \mathrm{~km}$. Regarding food security, two square meals per day and only occasional shortages of food are most typically reported. The highest educated adult in the family is literate and has completed up to 5 classes of primary schooling. Children between 4 and 15 years of age who are living in this median family have almost the same probability of going to school and not working as the probability of not going to school and working. Typically, the family is indebted (only less than a third of households are not in debt). These borrowings are mostly used for daily consumption purposes and are much more likely to originate from informal lenders rather than from a formal institutional agency. Importantly, the probability of being indebted significantly decreases with having regular salary employment (i.e. with not depending only on casual labor or on subsistence agriculture). Although the described median family is non-migrating, more than one-third of households in the region have experiences with migration. The most prevalent reason for migration is seeking casual work elsewhere, especially during the agricultural lean season.

This evidence can be for example compared to that presented in an interesting paper by Banerjee and Duflo (2007) who examined data from several household surveys conducted in different developing countries across the world in order to build an image of the way the extremely poor live their lives. 
In general, these local level figures confirm what has been indicated in section 2 on the basis of the all-India data. Perhaps the thorniest problem facing local villagers and, as this paper strives to emphasize, the main obstacle of the empowerment of rural regions in India relates to a lack of regular working opportunities or, possibly, to a lack of capacities (or, better, capabilities) to take advantage of existing opportunities. This is also obvious from another part of the BPL Census which additionally surveyed the preferences of villagers regarding the form of prospective assistance. In this regard, assistance in the form of the wage employment distribution programmes was reported as the most preferred, while those programmes focused on the improvement of housing were the second most preferred interventions. Also notably, these results additionally signified the important role of education. Not only do the perceived needs for assistance tend to decrease with the level of education, but, more interestingly, the preferences for the assistance programmes directed to self employment generation are significantly higher in the families where the adults have completed at least a few years of primary education in comparison to those with illiterate adult members.

\subsection{The Periyar PURA project}

The idea of PURA projects was originally raised as a key part of the vision "India 2020", which has been enthusiastically proposed by the former Indian president Abdul Kalam. In his dream of transforming India into a technologically and economically developed nation by 2020 , the PURA projects are planned as the models for the development of rural areas through the provision of what can be broadly defined as "urban infrastructure". It is suggested that the facilitation of various kinds of connectivity (physical, electronic, knowledge, and financial and market connectivity) to rural regions composed of the clusters of villages (with 10-15 villages in each cluster) will through various mechanisms of socioeconomic transformations of rural spaces eventually lead to the social and economic empowerment of local communities. At the same time, it promotes the facilitation of endogenous resources and skills (both known and tacit), rather than reliance on some external "driving forces". Through the provision of the necessary infrastructure and by supporting both agricultural and non-agricultural small-scale industries, the livelihood opportunities of small farmers, small entrepreneurs, and informal sector service producers will be diversified (Kalam, Rajan 2003; Indiresan 2004). The PURA concept can thus be comprehended as a vision of a balanced and targeted rural development strategy implemented at the grass roots level, one that is socially, economically, and environmentally sustainable. In spatial terms, the PURA concept calls for the spatial division of economic activities at the microregional scale (among the complexes of interconnected villages) determined by the careful consideration of local community specific potentials and needs. In addition, it gives emphasis to complementarities between physical and knowledge infrastructure, and to synergies between the public and private sectors (Sundaram 2008). Therefore, it differs remarkably from some earlier growthoriented rural strategies that were applied in rural India, which were based on the concentration of resources and rising agricultural productivity. ${ }^{7}$ 
The Periyar PURA belongs to several pivotal PURA projects that have already been operational across different parts of India. ${ }^{8}$ It was launched in 2003 under the auspices of Periyar Maniammai University, which is situated on the border of the targeted region. The general goal of this ongoing project has been to identify the needs of local villagers and address them by implementing appropriate activities. The staff and the students conducted a survey through the process of Participatory Rural Appraisal (e.g. Chambers 1994) and gathered information about the physical infrastructure, resources, population, cropping patterns, subsidiary avocation etc. The identified priority needs have then been addressed, one by one, by specific activities. These endeavours are implemented utilizing the natural resources for sustained development without endangering the environment. All of the 65 villages were grouped into seven clusters by considering the specific potentials of particular areas such as water availability, quality of soils, existing human resources etc. and different types of activities have been promoted in individual clusters.

In congruence with the original PURA concept, different kinds of connectivity (that can also be understood as different forms of capitals) have been supported. Regarding physical connectivity, the Periyar PURA initiative persuaded the district authorities to carry out several road improvement works. The central villages of particular clusters have been linked up by the all-weather roads both to each other and to the arterial Thanjavur - Trichy road, which crosses the region in the east-west direction. Besides the transport infrastructure, water related issues have attracted special attention. Since the chemical analysis uncovered contaminations of existing drinking water sources (the content of fluoride is a major problem), some alternate options have been sought and, in cooperation with a US based company, a model water purification plant was installed which brings the water within safe parameters. In addition, innovative water management techniques have been advocated for the conservation of water for irrigation. The percolation ponds and check dams have been developed to harness rainwater and the rehabilitation of existing water tanks has been undertaken. Some other infrastructural problems have also been addressed such as those related to health and sanitation (e.g. primary medical and paramedical centres, mobile medical vans, toilet and drainage facilities) among other relevant areas.

7 Some examples of such growth oriented initiatives were the Intensive Agricultural Area Programme, the High Yielding Varieties Programme, or the Intensive Cattle Programme launched in the $1960 \mathrm{~s}$. These and other programs within what has become known as the Green Revolution in India "demonstrated, on the one hand, the effectiveness of the concentration principle in achieving rapid increases in food production, and on the other hand, the failure of the growth-oriented strategy to solve the basic problems of rural poverty and income inequality" (Singh 2009, p. 189). It is suggested that rich farmers, mill owners, or money lenders gained most of the benefits, whereas the incomes of agricultural laborers reached their long-term minimum just after the introduction of the Green Revolution. While this is often associated with the "intrusion of capitalism into agriculture", it can also be seen as the culmination of a half century of declining real incomes of agricultural labor (Mayer 2006, p. 357).

8 For example, Chitrakoot PURA in Madhya Pradesh, Loni PURA in Maharashtra, Sakthi PURA project in Tamil Nadu, Byrraju PURA in Andhra Pradesh, Baktara PURA in Chhattisgarh, or Kalam PURA in Karnataka. 
Tab. 3 - Selected skill development training programmes - numbers of persons who participated up to 2008

\begin{tabular}{|lr|lr|}
\hline Agro-oriented & & Industry-oriented & \\
\hline Vermi composting & 823 & Welder & 318 \\
Bakery & 618 & Fitter & 143 \\
Bamboo cultivation & 368 & Carpenter & 122 \\
Coir products & 153 & Electrician & 85 \\
Sericulture (silk farming) & 120 & Turner & 27 \\
Apiculture (beekeeping) & 125 & Mechanic & 16 \\
Food processing & 125 & Female carpenter & 10 \\
\hline
\end{tabular}

Source: Periyar PURA records

Regarding electronic connectivity, village knowledge centres have been established, one in each cluster, in order to disseminate information and provide access to technologies. These knowledge centres have been connected with the university campus and with the Internet through WiMax technology. This can help to make rural people (of which most are on the wrong side of the digital divide) aware of the weather and various agricultural information, market rates for their products, government schemes, or it can be used for education enhancement and tele-medicine as well as for other purposes (see the discussion of potentials in Souter et al. 2009, for instance).

An important part of the Periyar PURA is the focus on knowledge and skill enhancement that could give birth to new job opportunities and entrepreneurship ventures. This is done by identifying and training local self help groups through Periyar Organization for Women Empowerment and Renaissance (POWER - see http://www.powerngo.org), a leading NGO, which forms a wing of the Periyar PURA programme. Regular vocational trainings are organized on various activities such as computer operation and numerous other agro-oriented and industry-oriented skills (see Table 3 for some examples).

In cooperation with specialists from Japan External Trade Organization, the prototypes of 123 products (such as bed sheets, cushion covers, brass drums, curtains, bread baskets etc.), for which competences and raw materials are available, have been developed. Some of these products have then been selected as suitable for external markets and marketing efforts and brand establishments have been provided according to the OVOP ("One Village One Product") strategy. ${ }^{9}$ Similarly, different kinds of alternative agro-based activities are promoted in each of the seven clusters according to identified potentials. These seven areas of specialization include the coir/coconut based products, alternative building materials, bamboo related products, herbal plant cultivation, integrated dairy production, focus on bio-fuels and alternative energy, and food processing and related activities. A model bio-farm has been established

9 The OVOP concept is a rural community-based revitalization strategy that was pioneered in the late 1970s in the Oita prefecture in Japan. It grew from the simple idea to encourage local communities (or villages and areas) to concentrate on one product (either tangible or intangible) that they do well and that reflect local resources, creativity, and culture and then produce it for external markets using an appropriate marketing and branding strategy with the emphasis on the principle of being "local yet global" (e.g. Fujita 2007). 
on what was originally dry barren land that was transformed using integrated watershed management so that it now also serves as an example for wasteland development. At this farm, training is given to the villagers on agricultural practices including the management of water resources through micro irrigation. It includes assistance with the cultivation of jatropha, a bio-fuel yielding plant that provides a source of renewable alternate fuel.

There are continuous attempts to ensure sustainability and potential for the scaling up of the above mentioned initiatives through the facilitation of market and financial linkages and the development of micro, small, and medium enterprises. It is done through the marketing of products, establishing interactions with bank and corporate institutions in the nearby regions, setting up self help groups (with a special focus on those for women) and providing them with help to access credit by the microfinance enhancement trainings. ${ }^{10}$

It is clear that the effects on regional development eventually induced by the interventions of Periyar PURA (as also described in the 2008 National Students Service Survey Report) can hardly be decoupled from other processes taking place in the region in question. Besides the operation of various government schemes and other non-government initiatives, a notable example of such a process is the upgrading of the central road between Thanjavur and Tiruchirappalli into the 4-lane expressway (labelled as NH-67) which is now being undertaken under the National Highways Development Project (see http://www.nhai.org). It is bound to have a major impact on the adjacent area and, in conjunction with the improvement of other roads, also on more distant parts of the region. So far, the belt is witnessing a rapid industrial development with a number of enterprises springing up along the highway.

Among other consequences, the prices of land, especially of those plots near the main road, have soared during recent years. However, this increase in the land prices has been noticed also in other parts of the region: according to the Periyar PURA records, the prices have increased from 1-19 Rupees per square meter in 2003 to $74-740$ Rupees per square meter in 2008 . Another factor that is related to this land valuation is the significant expansion of cultivated agricultural land (see Fig. 1), which is also due to the new irrigation and wasteland development practices. A few other figures additionally document positive ways forward such as an increase in the number of industries operating in the region from 13 in 2003 to 58 in 2008 which implies growing economic and entrepreneurial activity. Similarly, the number of self help groups has expanded from 850 to 2,000 during the same period and this suggests strengthened financial connectivity and development activity (self help groups are typically formed to access low cost financial services, which is followed by various self management development activities).

In spite of the fact that the figures mentioned above indicate general improvements in the considered region, this aggregate picture does not establish direct causality between individual Periyar PURA interventions and changes

10 Microfinance initiatives provide financial services to clients who do not have access to traditional banks because of lacking collateral or living in remote areas, for instance. In recent years, microfinance has been celebrated as one of the most effective development tools. In India, around 54 million clients are estimated to have been served by microfinance services until 2008 (Srinivasan 2009). 


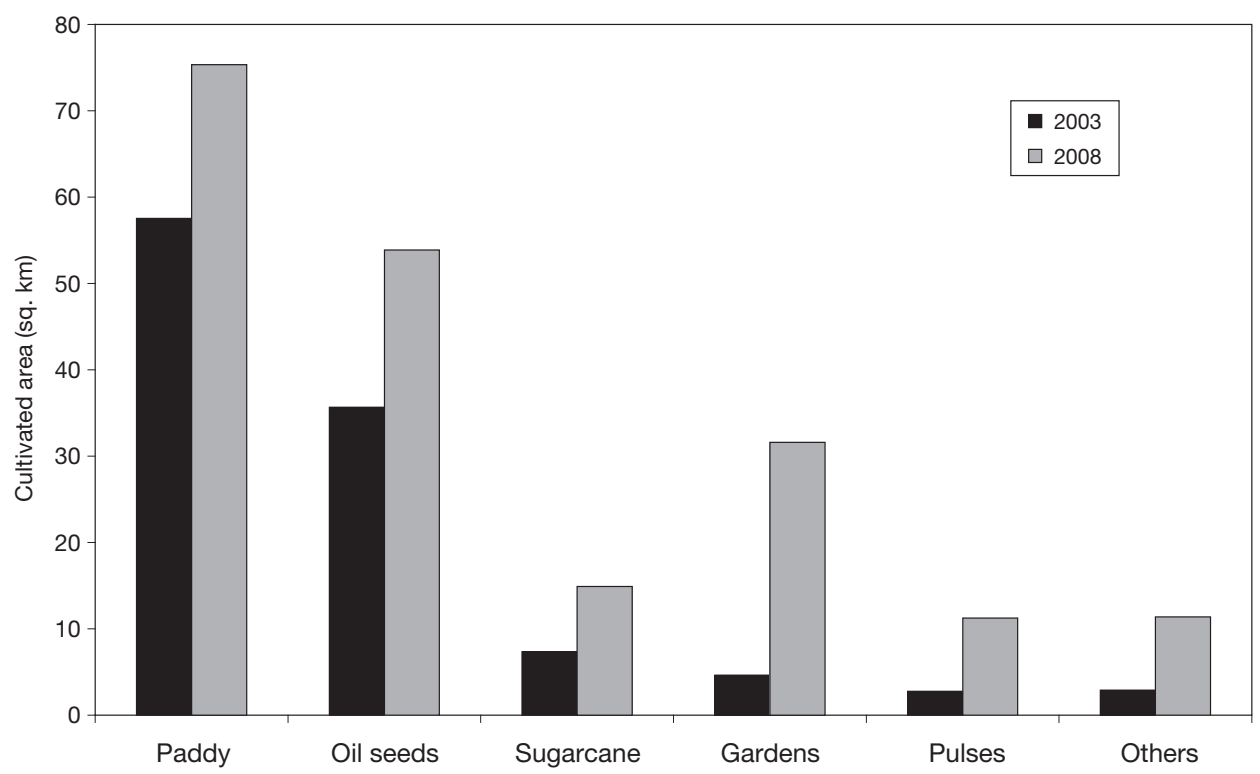

Fig. 1 - Area under cultivation in 2003 and 2008. Source: Periyar PURA survey.

in the situation of participating units (individuals, families, villages). In the case of some activities such as the provision of basic physical infrastructure, there are usually immediate and well recognizable impacts. However, regarding many other interventions (such as skill development trainings among others) the actual benefits have to be assessed from a longer term perspective. Ideally, all of the interventions should be subject to rigorous impact evaluation by considering their factual effects on the units that participated and comparing these findings with a counterfactual (control) group. So far, this type of information is scattered or limited to anecdotal evidence. For example, it is known that a number of people in the Acchampatti cluster, where the model bio-farm is located, have begun to follow similar agriculture practices on the land about which they had previously believed that it was completely unproductive. Similarly, there are known cases of local males who can marry only after acquiring a job once they have participated in the Periyar PURA scheme. However, these impacts still have to be properly quantified. Some detailed baseline data suitable for these purposes are available (consider the information provided in Section 3.1. of this article that refers to the 2002-2003 situation that can function well as the baseline). A comparison to more recent evidence by applying the modern impact evaluation methods (a substantial amount of relevant literature exists on impact assessment and development effectiveness evaluation), remains an important challenge that can help to improve effectiveness as well as help to legitimise similar development interventions in future. 


\section{Conclusion}

We opened this paper with a critical reference to World Development Report 2009 which calls for a strategy of spatially unbalanced economic development by advocating an "efficient and inclusive urbanization" without special need for interventions in lagging rural areas. By contrast, in this article an effort has been made to indicate that action is needed to attain more socially inclusive economic growth. There is no doubt about the importance of functioning markets, factor mobility, or agglomeration economies (though these issues can hardly be defined at hand). However, the ways and circumstances in which these forces work for both economic and human development in particular areas has to be more carefully scrutinized. The World Bank report uses the "discovery" of the inherent nature of spatial unbalances as a case for the policy that reinforces these unbalances and intensifies the rural - urban divides. On the contrary, the example presented here of a local development project, which attempts for a more balanced development and, implicitly, for the prevention of reasons for (involuntary) migration to extremely congested Indian cities. This attempt has been realized with a general focus on the enhancement of work and livelihood opportunities (the central topic of this article that links individual sections together) by capitalizing endogenous resources.

A few following remarks can be made to briefly summarize the discussion in this paper. In the first part of the article, the specific pattern of Indian socioeconomic development has been briefly mentioned. The overviewed material has shown that the assumptions of traditional modernization concepts assuming progressive structural transformation through industrialization and a progressive shift from an informal towards a more formal economy along the path of economic growth has only limited validity in India. Instead, a more complex pattern is suggested. It is characteristic by the coexistence of modern highly productive capital-intensive but insufficiently labor demanding economic activities alongside the rest of the mostly informal or unorganized component of Indian economy with limited interactions between these two segments. The increase of integration between these segments is undoubtedly a long-term intrinsic necessity. However, as the second part of the article has sought to exemplify, such development has to be catalyzed "from below", i.e. by the conscionable implementation of appropriate measures at local and regional level.

A case of the Periyar PURA project was described here as an example of the participatory rural development strategy which tries to empower local communities through identifying their needs and facilitating their endogenous potentials. While the design and experiences of this initiative undoubtedly offer vital inspiration for the replication of similar activities in other rural regions, some challenges have also been pointed out such as the need to apply appropriate impact assessment techniques. This can stimulate the effectiveness of particular development interventions as well as legitimise calls for scaling them up. At the same time, the area of impact evaluation also provides an example of possible future cooperation between researchers interested in development issues and Periyar PURA practitioners. 


\section{References:}

BANERJEE, A., DUFLO, E. (2007): The economic lives of the poor. The Journal of Economic Perspectives, 21, No. 1, pp. 141-167.

CAG (2007): Comptroller and Auditor General's (CAG) report on the performance of the NREGA I-III. Office of the Principal Director of Audit, Economic and Service Ministries, New Delhi.

CHAMBERS, R. (1994): Participatory rural appraisal (PRA): analysis of experience. World Development, 22, No. 9, pp. 1253-1268.

CHATTERJEE, P. (2007): Child malnutrition rises in India despite economic boom. The Lancet, 369, No. 9571, pp. 1417-1418.

CORBRIDGE, S., WILLIAMS, G., SRIVASTAVA, M., VÉRON, R. (2005): Seeing the State: Governance and Governmentality in India, Cambridge University Press, Cambridge, $317 \mathrm{p}$.

DASGUPTA, S., SINGH, A. (2005): Will services be the new engine of economic growth in India? Centre for Business Research, University of Cambridge, Working Paper No. 310.

DREZE, J., OLDIGES, CH. (2009): Work in progress. Frontline, 26, No. 4, pp. 101-105.

GOVERNMENT OF TAMIL NADU (2003): Tamil Nadu Human Development Report. Social Science Press, Delhi, 206 pp.

FUJITA, M. (2007): Spurring economic development by capitalizing on brand agriculture: turning development strategy on its head. In: Bourguignon, F., Pleskovic, B. (eds.) Rethinking Infrastructure for Development, Washington, World Bank, pp. 205-229.

Indian IT-BPO Industry 2009. National Association of Software and Services Companies (NASSCOM), www.nasscom.in.

INDIRESAN, P. V. (2004): A 20-20 Vision for India: targets, policies and implementation. Futures, 36, No. 6-7, pp. 679-692.

KALAM, A., RAJAN, Y. S. (2003): India 2020: A Vision for the New Millennium. Penguin Books India, $344 \mathrm{pp}$.

KOCHHRAN, K., KUMAR, U, RAJAN, R., SUBRAMANIAN, A, TOKATLIDIS, I. (2006): India's pattern of development: what happened, what follows? Journal of Monetary Economics, 53, No. 5, pp. 981-1019.

KRISHNA, A. (2007): For reducing poverty faster: target reasons before people. World Development, 35, No. 11, pp. 1947-1960.

LAL, D. (2008): An Indian economic miracle. Cato Journal, 28, No. 1, pp. 11-34.

LEWIS, W. A. (1954): Economic development with unlimited supplies of labor. Manchester School of Economic and Social Studies, 22, pp. 139-191.

MAYER, P. (2006): Trends in real income in Tiruchirapalli and the upper Kaveri Delta, 1819-1980: a footnote in honour of Dharma Kumar. Indian Economic Social History Review, 43, No. 3, pp. 349-364.

MOORE, M., JADHAV, V. (2006): The politics and bureaucratics of rural public works: Maharashtra's employment guaranteed scheme. Journal of Development Studies, 42, No. 8, pp. 1271-1300.

The Challenge of Employment in India: An Informal Economy Perspective. National Commission for Enterprises in Unorganized Sector, New Delhi 2009, 393 pp.

PIETERSE, J. N. (2010): Development Theory. Second Edition. SAGE Publications, London, $252 \mathrm{pp}$.

Eleventh Five Year Plan 2007-12. Volume I - Inclusive Growth. Planning commission, Oxford University Press, New Delhi 2008, 280 pp.

SAXENA, N. C. (2007): Rural poverty reduction through centrally sponsored schemes. Indian Journal of Medical Research, 126, No. 4, pp. 381-389.

SENGUPTA, A., KANNAN, K. P., RAVEENDRAN, G. (2008): India's common people: who are they, how many are they and how do they live? Economic and Political Weekly, 43, No. 11 , pp. $49-63$.

SHARMA, A. N. (2006): Flexibility, employment and labour market reforms in India. Economic and Political Weekly, May 27, pp. 2078-2085.

SINGH, K. (2009): Rural Development: Principles, Policies and Management. 3rd edition, Sage India, New Delhi, 368 pp. 
SOUTER, D. (ed.) (2005): The economic impact of telecommunications on rural livelihoods and poverty reduction: a study of rural communities in India (Gujarat), Mozambique and Tanzania. Report of DFID KaR Project 8347, UK Department for International Development, $447 \mathrm{pp}$.

SRINAVASAN, N. (2009): Microfinance India: State of the Sector Report 2008. Sage Publications India, New Delhi, $176 \mathrm{pp}$.

SUNDARAM, K. (2003): On identification of households below poverty line in BPL-census 2002: some comments on the proposed methodology. Economic and Political Weekly, 38, No. 9, pp. 896-901.

SUNDARAM, K. (2008): Beyond PURA and towards the next phase of rural renaissance. In: Dutt, A. K., Mishra, H. N., Chatterjee, M. (eds.): Explorations in Applied Geography, Prentice-Hall India, New Delhi, pp. 196-208.

Union Budget 2009-2010. Ministry of finance (2009), http://indiabudget.nic.in.

World Development Report 2009: Reshaping Economic Geography. The World Bank, Washington 2009, 383 pp.

\section{Shrnutí}

\section{ALTERNATIVA K „RŮSTU BEZ ZVYŠOVÁNÍ ZAMĚSTNANOSTI“? CELO-INDICKÝ KONTEXT A PŘÍKLAD PROJEKTU PARTICIPATIVNÍHO ROZVOJE Z RURÁLNÍHO TAMILNÁDU}

V Indii žije zhruba jedna šestina světové populace, ale podle existujících odhadů také celá třetina extrémně chudých tohoto světa. Více než dvě třetiny indického obyvatelstva se přitom stále nachází na venkově. Souběžně s dlouhodobě dynamickým ekonomickým růstem indické ekonomiky a její postupující (byt’ selektivní) integrací do systému globální dělby práce, je čím dál častěji poukazováno na omezené sociální přínosy příznivého makroekonomického vývoje. Tímto směrem je také zaměřen předložený článek, který některé z rozvojových problémů a výzev současné Indie diskutuje. Propojujícím aspektem jednotlivých částí článku je zdůraznění významu snah o posílení příležitostí zaměstnání a obecně životních příležitostí v rámci masivního „neorganizovaného“ sektoru indické ekonomiky. Obecným cílem je tak - v kontrastu k doporučením strategií (prostorově) nebalancovaného vývoje (viz např. World Development Report 2009) - poukázat na potřebu podpůrných intervencí v méně rozvinutých venkovských oblastech. Vedle velkých sociálních programů ŕízených shora federální či státními vládami (viz např. stávající masivní program známý jako tzv. National Rural Employment Guarantee Act, který zaručuje minimální pracovní př́ležitosti venkovským domácnostem), vidíme potenciál v projektech vycházejících z konceptů endogenního a participativního rozvoje aplikovaných na lokální a regionální úrovni.

V prvé části článku jsou na úrovni celé Indie ilustrovány některé základní trendy socioekonomického vývoje. Snažíme se zde poukázat na omezenou platnost tradičních rozvojových předpokladů založených na představě více či méně uniformního vzorce strukturální transformace v průběhu ekonomického rozvoje. Existující data ukazují, že dlouhodobý ekonomický růst Indie zatím neprovází adekvátní změny v růstu a struktuře zaměstnanosti (proto bývá někdy označován jako tzv. jobless-growth), ani postupný přesun zaměstnanosti z neformálního do formálního sektoru.

Druhá, stěžejní část článku pak přináší příkladovou studii venkovského regionu, který se nachází ve středovýchodním Tamilnádu. Nejdříve se zaměřujeme na základní charakteristiku daného regionu a rozbor problémů, se kterými se potýkají místní obyvatelé v jejich každodenním životě (k čemuž využíváme též detailních dat z tzv. Below Poverty Line cenzu). Dále pak představujeme a diskutujeme projekt s názvem Periyar PURA (Providing Urban Amenities to Rural Areas), který vychází z konceptů endogenního a participativního rozvoje, a který je koordinován místní univerzitou. Tento projekt se různými typy aktivit snaží posílit sociální i ekonomické postavení venkovských komunit, zmobilizovat jejich vnitřní potenciál a diverzifikovat možnosti prríjmu místních domácností. Přestože lze doložit některé příznivé trendy rozvoje dotčeného regionu a existují i některé dílčí informace o konkrétních přínosech aktivit realizovaných v rámci diskutovaného projektu, tyto aktivity nebyly podrobeny exaktním hodnocením dopadi̊. Projekt tak trpí velmi obvyklým nedostatkem rozvojových 
intervencí, když neexistují dostatečně reprezentativní data, která by průkazně dokládala jejich efektivitu a dokazovala př́činné souvislosti mezi jednotlivými opatřeními a rozvojem daného regionu. Provedení takovýchto hodnocení je zásadní výzvou do budoucna a může pomoci legitimizovat podporu obdobných modelů rozvoje v jiných regionech.

Obr. 1 -Rozloha zemědělsky obdělávané půdy v roce 2003 a 2008. Osa x - rýže, olejniny, cukrová třtina, zahrady, čočka, ostatní. Zdroj: šetření Periyar PURA.

J. Novotny is affiliated with Charles University in Prague, Faculty of Science, Department of Social Geography and Regional Development, Albertov 6, 12843 Praha 2, Czechia; e-mail: pepino@natur.cuni.cz. J. Ramachandran is Vice-Chancellor of Periyar Maniammai University, Thanjavur, 613403, India, e-mail vc@pmu.edu.

Initial submission 7 December 2009; final acceptance 25 May 2010.

\section{Citační vzor:}

NOVOTNÝ, J., RAMACHANDRAN, N. (2010): Alternative to jobless growth? All-India context and a case of participatory development scheme from rural Tamil Nadu. Geografie, 115, č. 3 , s. 330-346. 